\title{
Tomi Kaarto in memoriam
}

Filosofian lisensiaatti, assistentti Tomi Kaarto menehtyi äkillisesti 20.10.2006 vain 34vuotiaana.Hän oli syntynyt 13.6.1972 Turussa. Hän opiskeli Turun yliopistossa yleistä kirjallisuustiedettä ja filosofiaa ja toimi siellä sen jälkeen yleisen kirjallisuustieteen assistentin tehtävissä vuodesta 1996 lähtien.

Tomi Kaarto oli poikkeuksellisen lahjakas teoreettinen ajattelija, joka jo varhain ryhtyi pohtimaan sangen itsenäisesti kirjallisuustieteen perustana olevia filosofisia kysymyksiä. Hänen ensimmäinen laaja julkaisunsa koski Mihail Bahtinin ja Michel Foucault'n kirjailijakäsitystä. Tämän jälkeen hänen kiinnostuksensa kohteeksi tuli erityisesti ranskalaisen nykyfilosofian klassikko Jacques Derrida. Tomi Kaarto ehti saavuttaa Suomessa näkyvyyttä useilla Derridaa koskevilla esitelmillään ja kirjoituksillaan, joissa hän pystyi johdattamaan kuulijansa erinomaisen selkeästi tämän viime vuosisadan kenties vaikeaselkoisimman filosofin ajatteluun. Hänen viimeiseksi työkseen jäi laaja Derridaa koskeva väitöskirja, jossa hän tarkastelee Derridan ajattelussa keskeisen dekonstruktion suhdetta Edmund Husserlin reduktion menetelmään.

Työtoverit, opiskelijat ja ystävät jäävät kaipaamaan Tomi Kaarrossa teoreettiselle ajattelulle antautunutta, vaikeimpiakaan kysymyksiä kaihtamatonta tutkijaa, innostavaa opettajaa sekä ystävällistä, huumorintajuista ihmistä. Tomi Kaarto oli intohimoinen keskustelija, jonka kanssa oli mahdollista paneutua laaja-alaisesti erilaisiin kirjallisuusteorian ja filosofian kysymyksiin jatkuvaa, molemminpuolista oppimisen ja oivaltamisen iloa tuntien. Universitas-ajatus tai ajatus oppineiden/oppivien yhteisöstä avoimen keskustelun yhteisönä toteutui tässä harvinaisella tavalla.

\section{Liisa Saariluoma}

kirjoittaja on professori ja Tomi Kaarron läheinen työtoveri 